\title{
Enhancement of Sweet Pepper Fruits Quality and Storability by Some Postharvest Treatments.
}

\author{
Mohamed A. A Abdullah ${ }^{1}$ and Hany A. M. Srour ${ }^{2}$ \\ 1- Vegetable Handling Dept., Horticulture Research Institute, Agriculture Research Center, P.O. Box 12619, \\ Orman, Giza, Egypt. \\ 2- Biochemistry Dept., Faculty of Agriculture, Ain Shams Univ., P.O. Box 68, Hadayek Shubra 11241, Cairo, \\ Egypt. \\ Corresponding author: mohmedabdalla80@yahoo.com
}

\begin{abstract}
Sweet pepper fruit is one of the most sensitive crops to postharvest conditions. Storage and handling procedure of sweet pepper fruits lead to remarkable reduction in the fruit quality. The objective of this study is to enhance fruit quality and storability by some postharvest treatments with $1.5 \%$ of 1 -Methylcyclopropene for 5 minutes, $1.5 \%$ calcium chloride $\mathrm{CaCl}_{2}$ for 5 minutes, hot water at $45^{\circ} \mathrm{C}$ for 2 minutes or tap water for 5 minutes which served as control. Sweet pepper fruits were harvested with $75 \%$ fruit coloration. The results clearly indicated that dipping of sweet pepper fruits in a solution of 1.5\% of 1-Methylcyclopropene for 5 minutes reduced the weight loss and maintained fruit firmness, total soluble solids, ascorbic acid content and external surface color, compared to the other treatments. The observed effects of 1-Methylcyclopropene on the fruit quality and storability could be due to its effect on Polyphenol oxidase (ppo), whereas the activity of ppo was inhibited by 1-Methylcyclopropene. Also, 1-Methylcyclopropene and calcium chloride treatments reduced the decay and maintained general appearance compared to other treatments.
\end{abstract}

Keywords: sweet pepper fruits - 1-Methylcyclopropene - Calcium chloride - Polyphenol oxidase.

\section{Introduction}

Sweet pepper is a climacteric fruit and is prone to water loss and consequently shriveling through to their large surface to weight ratio. Sweet pepper is susceptible to fungal infections which may lead to postharvest losses to the growers if not controlled. Further, problem is aggravated during production when farmers try to store their production for short periods to avoid low market prices. But, nonavailability of proper storage facilities in production areas and lack of knowledge regarding postharvest handling lead to huge post-harvest losses. Such losses can be overcome by the use of appropriate technology with a potential to retain the storage quality of the freshly harvested produce (Thakur $\boldsymbol{e t}$ al., 2017).

The patenting and discovery of cyclopropenes as inhibitors of ethylene recognition exemplify important leap in controlling ethylene responses of vegetables crops. Regulatory approval has been obtained in more than 50 countries for use of 1-MCP. 1-Methylcyclopropene is recorded for use on many varieties of fresh vegetables such as melon, cucumber, broccoli, pepper, squash and tomato. 1MCP affects many senescence and ripening processes (Watkins, 2006 and Huber et al., 2010), such as pigment changes, cell wall metabolism and softening, odor and flavor and natural characteristics (Huber, 2008 and Watkins, 2008). Also, calcium has been reported to maintain cell integrity and firmness of fruits during storage (Ochie et al., 1993). Calcium chloride solution approach to maintain quality and extend the storage life. Nirupama et al., 2010, recommended lower concentration such as $1.5 \% \mathrm{CaCl}_{2}$, Senevirathna and Daundasekera (2010) recommended higher concentration such as $6 \% \mathrm{CaCl}_{2}$. In addition, using hot water to increase the shelf life is corelated to its effects on the physiological processes such as a delay of ripening processes (Lurie, 1998), elimination of insect pollution and control of fungal infections (Schirra et al., 2000). Exposure of sweet pepper fruits to heat or hot water can cause severe internal and external damage. Tissue damage caused by heat also results in increased susceptibility to decay development. Evidence of internal damage can include poor color development, flesh softening, and development of internal cavities (Glowacz et al., 2013; Sivakumar and Fallik, 2013)

The aim of the present study is to enhance the quality of sweet pepper fruits by applying 1Methylcyclopropene, calcium chloride $\mathrm{CaCl}_{2}$ or hot water at $45^{\circ} \mathrm{C}$. Evaluation of these treatments and their effects on the quality of the sweet pepper fruits and storability has been carried out.

\section{Material and Methods}

Sweet pepper seedlings (Capsicum annuum L. cv. 7802 F1 hybrid) were transplanted in September in two growing seasons (2015-2016 and 2016-2017). Sweet pepper plants were grown under greenhouses conditions of El-Iman Farm, Wadi Natrun, Elbehira Governorate, Egypt. After 80 days of transplantation, sweet pepper fruits were harvested at the commercial 
maturity (red stage) with uniform size and color (75\% coleration) with a short calyx (1 cm long) and then transported immediately to the Vegetable Handling Department and kept overnight at $10^{\circ} \mathrm{C}$ with $90-95 \%$ relative humidity. The following morning sweet pepper fruits were carefully selected, free of visual damage or defects, washed initially with water, then air dried. The fruits were divided into four groups each group contains 18 replicates (about 500g fruits per each replicate) then the fruits were dipping in $1.5 \%$ 1-Methylcyclopropene for 5 minutes, $1.5 \%$ calcium chloride $\mathrm{CaCl}_{2}$ for 5 minutes, hot water at $45^{\circ} \mathrm{C}$ for 2 minutes or tap water for 5 minutes which served as control.

Samples were randomly taken from the three replicates and arranged in a factorial complete randomized design and stored at $10^{\circ} \mathrm{C}$ and $90-95 \%$ relative humidity for 35 days. The treatments were examined immediately after harvest and every seven days intervals for the following parameter.

Weight loss percentage: The percentage of weight loss of the sweet pepper fruits were estimated according to the following equation: Weight loss $\%=$ [(Initial weight - weight of fruits at sampling date)/Initial weight of fruits] x 100 according to Shehata et al., 2013.

Decay score: Sweet pepper fruit decay was determined according to Shehata et al., 2013 as score system of $1=$ none, $2=$ slight, $3=$ moderate, $4=$ moderately severe, $5=$ severe. This depends on decay percentage on fruits.

General appearance score: it was determined as score system of excellent $>9$, good $>7$ to 8.9 , fair $>5$ to 6.9 , poor $>3$ to 4.9 , and unassailable> 2.9. The scale depends on morphological defects such as shriveling, fresh appearance, color change of fruits and decay. Fruits rating (5) or below considered unmarketable according Shehata et al., 2013.

Firmness: the average firmness of the fruits was measured in $\mathrm{kg} / \mathrm{cm}^{2}$ by digital force Gauge model FGV 50 A, Shimpo Instrument Co, Japan, with total capacity of $20 \mathrm{~kg} / \mathrm{cm}^{2}$ and resolution of $0.01 \mathrm{~kg} / \mathrm{cm}^{2}$ using cone pointed head.

Total soluble solids percentage (TSS): Total soluble solids content was determined in sweet pepper fruit juice sample by digital refractometer of model Abbe Leica according to the method described by (A.O.A.C., 2012).

Ascorbic acid content was determined using the dye 2, 6-dichloro-phenol indophenols method (A.O.A.C., 2012).

External surface color: External surface color was evaluated by a color difference meter (Minolta CR200) to measure the $L^{*}$ describes lightness $\left(L^{*}=0\right.$ for black, $L^{*}=100$ for white) and $b^{*}$ describes intensity in yellow-green $\left(b^{*}>0\right.$ for yellow, $b^{*<0}$ for green).

Polyphenol oxidase (ppo): Crude extract of ppo was prepared by homogenizing fruit samples with volume of 5 fold of their weight of sodium phosphate buffer (0.1 mM, pH 6.5) containing $30 \mathrm{mM}$ sodium ascorbate and $0.4 \mathrm{M}$ sucrose at $25^{\circ} \mathrm{C}$. The fruit homogenate was centrifuged at $10000 \mathrm{~g}$ for $15 \mathrm{~min}$. Supernatant was collected and stored at $4^{\circ} \mathrm{C}$. Catechol was dissolved in the phosphate buffer (10 $\mathrm{mM}$ ) then a volume of $3 \mathrm{~mL}$ was mixed with 1.0 enzyme extract. The increment of absorption of 495 $\mathrm{nm}$ was spectrophotometrically recorded. The increase in absorbance of 0.01 per minute at $495 \mathrm{~nm}$ at the specified condition was defined as one unit of PPO activity. The results were expressed as IU per mg protein according to Dogan $\boldsymbol{e t}$ al., 2002.

Statistical analysis: Data of the two seasons were arranged and statistically analyzed using Mstatic. Two way analysis of variance of the different treatments was carried out by using Duncan's test. The data were tabulated and statistically analyzed according to a factorial complete randomized design (Snedecor and Cochran 1982).

\section{Results and Discussion}

\subsection{Weight loss percentage:-}

Data in Table (1) show the effect of 1Methylcyclopropene, calcium chloride and hot water on weight loss percentage of sweet pepper fruits during storage. The results demonstrated that weight loss percentage of sweet pepper fruits was increased considerably and consistently with the prolongation of storage period in the fruits obtained from both two seasons. These might be due to the loss in moisture through transpiration and loss in dry matter content due to respiration during storage. These findings are in agreement with (Smith $\boldsymbol{e t}$ al,. 2006, FernándezTrujillo et al., 2009 and Ilic et al., 2009).

Concerning the effect of some postharvest treatments, data revealed that there were significant differences among treatments in weight loss percentage during storage. All postharvest treatments retained their weight during storage as compared with untreated control. Moreover, dipping sweet pepper fruits treated for 5 minutes in 1Methylcyclopropene $(1.5 \%)$ was the most effective treatment in reducing the percentage of weight loss $\%$ followed by dipping in $1.5 \%$ calcium chloride $\mathrm{CaCl}_{2}$ for 5 minutes. The highest value of weight loss percentage was recorded with untreated control. These results were achieved in the two seasons and were in agreement with Ibrahim and Abdullah (2018) who found that fruits exposed to different level concentrations of 1-Methylcyclopropene gave the lowest value of weight loss percent compared to untreated as control for sweet pepper and tomato fruits. 
The Interaction between storage period and treatments on weight loss was significant. There was an increase in fruit weight loss in each treatment towards the end of storage period. However, the reduction in weight loss was very sharp after 35 days of storage in all treatments.

\subsection{Decay score:-}

Data in Table (1) indicate that effect of some postharvest treatments on decay score of sweet pepper fruits during storage. Data clear that the decay started slowly and increased with the prolongation of storage period in the two seasons may be through the continuous chemical and biochemical changes happened in the fruits (Ilic et al., 2014).

Examined all treatments used were lowest decay score in comparison to control. Moreover, sweet pepper fruits treated for 1-Methylcyclopropene
(1.5\%) or $1.5 \%$ calcium chloride $\mathrm{CaCl}_{2}$ were the most effective treatments in reducing the decay. The highest value of decay score was recorded with untreated treatment (control).

1-Methylcyclopropene and calcium chloride using to delaying, slowing ripening fruit and maintaining quality during the storage period. These results are in agreement with Fernández- Trujillo et al., 2009, Ilic et al., 2009, Ilic et al., 2012 and Ibrahim and Abdullah, 2018.

For the interaction among treatments and storage period, data show that, the decay of untreated fruits started to be shown after 7 days of storage and several symptoms of decay at the end of storage period were observed, while no decay was noticed in fruits treated with 1-Methylcyclopropene or calcium chloride $\mathrm{CaCl}_{2}$ till 21 days in both season.

Table 1. Effect of some postharvest treatments on weight loss \%, decay and general appearance of sweet pepper fruits during storage at $10^{\circ} \mathrm{C}$ in 2015 and 2016 seasons.

\begin{tabular}{|c|c|c|c|c|c|c|c|c|c|c|c|c|c|}
\hline \multirow[b]{2}{*}{ Treatments } & \multirow{2}{*}{$\begin{array}{c}\text { Days } \\
\text { after } \\
\text { storage }\end{array}$} & \multicolumn{6}{|c|}{ First season (2015) } & \multicolumn{6}{|c|}{ Second season (2016) } \\
\hline & & \multicolumn{2}{|c|}{$\begin{array}{l}\text { Weight } \\
\text { loss \% }\end{array}$} & \multicolumn{2}{|c|}{ Decay } & \multicolumn{2}{|c|}{$\begin{array}{c}\text { General } \\
\text { appearance }\end{array}$} & \multicolumn{2}{|c|}{$\begin{array}{l}\text { Weight } \\
\text { loss \% }\end{array}$} & \multicolumn{2}{|c|}{ Decay } & \multicolumn{2}{|c|}{$\begin{array}{c}\text { General } \\
\text { appearance }\end{array}$} \\
\hline \multirow{6}{*}{ MCP $1.5 \%$} & $\mathbf{0}$ & & & 1.00 & $\mathrm{f}$ & 9.00 & $\bar{a}$ & & & 1.00 & $\mathrm{~g}$ & 9.00 & $\bar{a}$ \\
\hline & 7 & 1.03 & $\mathrm{t}$ & 1.00 & $\mathrm{f}$ & 9.00 & $\mathrm{a}$ & 1.33 & $\mathrm{p}$ & 1.00 & g & 9.00 & $\mathrm{a}$ \\
\hline & 14 & 2.33 & $\mathrm{p}$ & 1.00 & $\mathrm{f}$ & 9.00 & $\mathrm{a}$ & 2.94 & $\mathrm{~m}$ & 1.00 & $\mathrm{~g}$ & 9.00 & $\mathrm{a}$ \\
\hline & 21 & 3.94 & 1 & 1.00 & $\mathrm{f}$ & 9.00 & $\mathrm{a}$ & 4.31 & $\mathrm{j}$ & 1.00 & $\mathrm{~g}$ & 9.00 & $\mathrm{a}$ \\
\hline & 28 & 5.13 & $\mathrm{~h}$ & 1.33 & ef & 8.33 & $a b$ & 5.61 & $\mathrm{~h}$ & 1.67 & efg & 7.67 & $a b c$ \\
\hline & 35 & 7.45 & $\mathrm{e}$ & 1.33 & ef & 8.33 & $a b$ & 7.82 & $\mathrm{~d}$ & 2.33 & cdef & 6.33 & bcd \\
\hline \multirow{6}{*}{$\mathrm{CaCl} 25 \%$} & $\mathbf{0}$ & & & 1.00 & $f$ & 9.00 & $\mathrm{a}$ & & & 1.00 & $\mathrm{~g}$ & 9.00 & $\mathrm{a}$ \\
\hline & 7 & 1.23 & s & 1.00 & $f$ & 9.00 & $\mathrm{a}$ & 1.53 & o & 1.00 & $\mathrm{~g}$ & 9.00 & $\mathrm{a}$ \\
\hline & 14 & 2.46 & o & 1.00 & $f$ & 9.00 & $\mathrm{a}$ & 3.14 & 1 & 1.00 & $\mathrm{~g}$ & 9.00 & $\mathrm{a}$ \\
\hline & 21 & 4.13 & $\mathrm{k}$ & 1.00 & $f$ & 9.00 & $\mathrm{a}$ & 4.69 & $\mathrm{i}$ & 1.33 & $\mathrm{fg}$ & 8.33 & $a b$ \\
\hline & 28 & 5.21 & $\mathrm{~g}$ & 1.67 & def & 7.67 & $a b c$ & 5.77 & gh & 2.00 & defg & 7.00 & abcd \\
\hline & 35 & 7.63 & $\mathrm{~d}$ & 2.00 & cdef & 7.00 & abcd & 8.07 & $\mathrm{c}$ & 3.00 & bcd & 5.00 & de \\
\hline \multirow{6}{*}{ Hot water } & 0 & & & 1.00 & $\mathrm{f}$ & 9.00 & $\mathrm{a}$ & & & 1.00 & $\mathrm{~g}$ & 9.00 & $\mathrm{a}$ \\
\hline & 7 & 1.31 & $r$ & 1.00 & $\mathrm{f}$ & 9.00 & $\mathrm{a}$ & 1.66 & o & 1.00 & $\mathrm{~g}$ & 9.00 & $\mathrm{a}$ \\
\hline & 14 & 2.86 & $\mathrm{n}$ & 1.33 & ef & 8.33 & $a b$ & 3.42 & $\mathrm{k}$ & 1.67 & efg & 7.67 & $a b c$ \\
\hline & 21 & 4.44 & j & 1.67 & def & 7.67 & $a b c$ & 5.92 & $\mathrm{fg}$ & 2.00 & defg & 7.00 & abcd \\
\hline & 28 & 5.62 & $\mathrm{f}$ & 2.33 & bcde & 6.33 & bcde & 6.05 & $\mathrm{f}$ & 2.67 & bcde & 5.67 & cde \\
\hline & 35 & 8.02 & $\mathrm{~b}$ & 2.67 & bcd & 5.67 & cde & 8.94 & $\mathrm{~b}$ & 3.67 & $\mathrm{ab}$ & 3.67 & ef \\
\hline \multirow{6}{*}{ Control } & $\mathbf{0}$ & & & 1.00 & $\mathrm{f}$ & 9.00 & $\mathrm{a}$ & & & 1.00 & $\mathrm{~g}$ & 9.00 & $\mathrm{a}$ \\
\hline & 7 & 1.46 & $\mathrm{q}$ & 1.67 & def & 7.67 & $a b c$ & 1.85 & $\mathrm{n}$ & 2.00 & defg & 7.00 & abcd \\
\hline & 14 & 3.13 & $\mathrm{~m}$ & 2.33 & bcde & 6.33 & bcde & 4.34 & $\mathrm{j}$ & 2.67 & bcde & 5.00 & de \\
\hline & 21 & 5.06 & $\mathrm{i}$ & 3.00 & $\mathrm{bc}$ & 5.00 & de & 6.54 & $\mathrm{e}$ & 3.00 & bcd & 5.00 & de \\
\hline & 28 & 7.90 & $\mathrm{c}$ & 3.33 & $a b$ & 4.33 & ef & 8.83 & $\mathrm{~b}$ & 3.33 & $\mathrm{bc}$ & 3.67 & ef \\
\hline & 35 & 10.13 & $\mathrm{a}$ & 4.33 & $\mathrm{a}$ & 2.33 & $\mathrm{f}$ & 11.12 & $\mathrm{a}$ & 4.67 & $\mathrm{a}$ & 1.67 & $\mathrm{f}$ \\
\hline МCP $1.5 \%$ & & 3.98 & $\mathrm{D}$ & 1.11 & $\mathrm{C}$ & 8.78 & $\mathrm{~A}$ & 4.40 & $\mathrm{D}$ & 1.33 & $\mathrm{C}$ & 8.33 & A \\
\hline CaCl2 5\% & & 4.13 & $\mathrm{C}$ & 1.28 & $\mathrm{C}$ & 8.44 & A & 4.64 & $\mathrm{C}$ & 1.56 & $\mathrm{C}$ & 7.89 & A \\
\hline Hot water & & 4.45 & $\mathrm{~B}$ & 1.67 & B & 7.67 & B & 5.20 & $\mathrm{~B}$ & 2.00 & B & 7.00 & B \\
\hline \multirow[t]{7}{*}{ Control } & & 5.54 & $\mathrm{~A}$ & 2.61 & A & 5.78 & $\mathrm{C}$ & 6.53 & $\mathrm{~A}$ & 2.78 & A & 5.22 & $\mathrm{C}$ \\
\hline & 0 & & & 1.00 & $\mathrm{C}$ & 9.00 & $\mathrm{~A}$ & & & 1.00 & $E$ & 9.00 & $\mathrm{~A}$ \\
\hline & 7 & 1.26 & $\mathrm{E}$ & 1.17 & $\mathrm{C}$ & 8.67 & A & 1.59 & $\mathrm{E}$ & 1.25 & $\mathrm{DE}$ & 8.50 & A \\
\hline & 14 & 2.69 & $\mathrm{D}$ & 1.42 & $\mathrm{BC}$ & 8.17 & $\mathrm{AB}$ & 3.46 & $\mathrm{D}$ & 1.58 & $\mathrm{CD}$ & 7.67 & B \\
\hline & 21 & 4.39 & $\mathrm{C}$ & 1.67 & B & 7.67 & $\mathrm{~B}$ & 5.36 & $\mathrm{C}$ & 1.83 & $\mathrm{C}$ & 7.33 & B \\
\hline & 28 & 5.97 & B & 2.17 & A & 6.67 & $\mathrm{C}$ & 6.57 & B & 2.42 & B & 6.00 & $\mathrm{C}$ \\
\hline & 35 & 8.31 & A & 2.58 & A & 5.83 & $\mathrm{C}$ & 8.99 & A & 3.42 & A & 4.17 & $\mathrm{D}$ \\
\hline
\end{tabular}

Values followed by the same letter (s) are not significantly different at $5 \%$. 


\subsection{General appearance score:-}

Data in Table (1) show the effect of some postharvest treatments on general appearance (Score) of sweet pepper fruits during storage. Results indicated that there was significant reduction in GA of sweet pepper fruits with the prolongation of storage period in both seasons. The decrease of general appearance during the storage period might be due to a slight dryness of surface; instead of translucency or macroscopic decay as expected Similar results were reported by Ilic et al., 2014.

Concerning the effect of postharvest treatments, data revealed that there were significant differences between postharvest treatments and untreated control during storage. Sweet pepper fruits treated with all postharvest treatments had significantly the highest score of appearance as compared with untreated control. However, sweet pepper fruits treated with 1Methylcyclopropene $(1.5 \%)$ and calcium chloride $\mathrm{CaCl}_{2} \quad 1.5 \%$ were the most effective treatments for maintaining general appearance with no significant differences between them, followed by dipped in hot water at $45^{\circ} \mathrm{C}$ for 2 minutes while untreated control recorded the lowest ones in this concern. These results were achieved in the two seasons.

1-Methylcyclopropene and calcium chloride acts as a semipermeable barrier on the surface of fruit and vegetables against oxygen, carbon dioxide and moisture, thereby reducing respiration, water loss, respiratory activity and degradation by enzymes and microbial rot of fruits (Shehata et al., 2009 and Ilic et al., 2012). As for the interaction between postharvest treatments and storage period, data revealed that fruits dipped in solution 1Methylcyclopropene and calcium chloride did not exhibit any changes in their appearance till 21 days, of storage. On the other hand, untreated fruits had the poorest appearance at the end of storage period (35 days). These results were true in both seasons.

\subsection{Firmness}

Data in Table (2) show the effect of some postharvest treatments on firmness of sweet pepper fruits during storage. Data indicated that there was a significant reduction in firmness of sweet pepper fruits by the prolongation of storage period in the two seasons. The decrease in firmness during storage could be related to the development of fungal growth and the increase in the metabolism which increase the enzymatic activity. Similar results were obtained by (Gonzalez-Aguilar et al., 2004).

Concerning the effect of postharvest treatments, data revealed that all postharvest treatments had a significant effect on fruit firmness as compared with untreated control during storage. However, sweet pepper fruits treated with1-Methylcyclopropene (1.5\%) gave the highest value of fruit firmness during storage followed by calcium chloride $\mathrm{CaCl}_{2}$ $(1.5 \%)$, while the hot water at $45^{\circ} \mathrm{C}$ treatments were less effective in this concern. The lowest value of fruit firmness was obtained from untreated control. These results were achieved in the two seasons and were in agreement with Fernández-Trujillo et al., 2009 and Ilic et al., 2009.

The effect of interaction between treatments and storage period was significant on fruit firmness in both seasons. Fruits from all treated treatments during storage period were significantly firmer than those of untreated (control).

\subsection{Total soluble solids percentage}

Data in Table (2) show the effect of some postharvest treatments on total soluble solids percentage of sweet pepper fruits during storage. Data indicated that total soluble solids of sweet pepper fruits decreased with the prolongation of storage till the end of storage period in both seasons, these results are similar with Ibrahim and Abdullah, 2018.

Regarding the effect of postharvest treatments, data revealed that there were significant differences between postharvest treatments and untreated control in TSS \% of sweet pepper fruits during storage. Sweet pepper fruits treated with 1Methylcyclopropene (1.5\%) retained more TSS percentage, followed by calcium chloride $\mathrm{CaCl}_{2}$ $(1.5 \%)$. Fruits from all treatments during storage period were higher in their total sugar and T.S.S. than those of untreated (control). Moreover, fruit treated with 1-Methylcyclopropene during storage period had slightly highest T.S.S. compared with other treatments during storage period.

\subsection{Ascorbic acid content}

Data in Table (2) show the effect of some postharvest treatments on ascorbic acid content of sweet pepper fruits during storage. Data indicated that ascorbic acid content decreased with the prolongation of storage till the end of storage period in both seasons. Reduction in ascorbic acid content during storage period might have been due to the higher rate of sugar loss through respiration than water loss through transpiration, these results are similar with Raffo $\boldsymbol{e t}$ al., 2008.

Regarding the effect of postharvest treatments, data showed that all postharvest treatments were effective in preventing ascorbic acid degradation during storage as compared with untreated control. Moreover, sweet pepper fruits treated with 1Methylcyclopropene (1.5\%) were the most effective treatments in maintaining ascorbic acid contents, followed by calcium chloride $\mathrm{CaCl}_{2}$ (1.5\%). The lowest values resulted in untreated control. These results were achieved in the two seasons and were in agreement with those obtained by Madhavi and Salunke, 1998, Lee and Kader, 2000 and Sabir $e t$ al., 2012. The effect of interaction between treatments and storage period was significant on fruit ascorbic acid content in both seasons. All treatments at different storage periods had higher ascorbic acid 
content than those that untreated fruits (control). Moreover, fruits treated with 1-Methylcyclopropene $(1.5 \%)$ at all different storage periods contained higher concentration ascorbic acid than other treatments or the control; on the contrary, control fruits had the lowest concentration of ascorbic acid.
The interaction among treatments and storage period, showed that fruits dipped in 1methylcyclopropene gave the best treatment for inhibit the activity of polyphenol oxidase after 35 days of storage compared to all other tested treatments in both seasons.

Table 2. Effect of some postharvest treatments on firmness $(\mathrm{kg} / \mathrm{cm} 2)$, total soluble solids \% and Ascorbic acid of sweet pepper fruits during storage at $10^{\circ} \mathrm{C}$ in 2015 and 2016 seasons.

\begin{tabular}{|c|c|c|c|c|c|c|c|c|c|c|c|c|c|}
\hline \multirow[b]{2}{*}{ Treatments } & \multirow[b]{2}{*}{$\begin{array}{c}\text { Days } \\
\text { after } \\
\text { storage }\end{array}$} & \multicolumn{6}{|c|}{ First season (2015) } & \multicolumn{6}{|c|}{ Second season (2016) } \\
\hline & & \multicolumn{2}{|c|}{$\begin{array}{l}\text { Firmness } \\
(\mathrm{kg} / \mathrm{cm} 2)\end{array}$} & \multicolumn{2}{|c|}{$\begin{array}{c}\text { Total } \\
\text { soluble } \\
\text { solids \% }\end{array}$} & \multicolumn{2}{|c|}{$\begin{array}{l}\text { Ascorbic } \\
\text { acid }\end{array}$} & \multicolumn{2}{|c|}{$\begin{array}{l}\text { Firmness } \\
(\mathrm{kg} / \mathrm{cm} 2)\end{array}$} & \multicolumn{2}{|c|}{$\begin{array}{c}\text { Total } \\
\text { soluble } \\
\text { solids \% } \\
\end{array}$} & \multicolumn{2}{|c|}{$\begin{array}{l}\text { Ascorbic } \\
\text { acid }\end{array}$} \\
\hline \multirow{6}{*}{ MCP $1.5 \%$} & $\mathbf{0}$ & 6.01 & $\mathrm{a}$ & 8.50 & $\mathrm{a}$ & 120.80 & $\mathrm{a}$ & 5.93 & $\mathrm{a}$ & 8.30 & $\bar{a}$ & 119.50 & $\mathrm{a}$ \\
\hline & 7 & 5.76 & $\mathrm{~b}$ & 8.27 & $\mathrm{~b}$ & 116.40 & $\mathrm{~b}$ & 5.55 & $\mathrm{~b}$ & 8.07 & $\mathrm{~b}$ & 115.40 & $\mathrm{~b}$ \\
\hline & 14 & 5.34 & $\mathrm{e}$ & 8.03 & $\mathrm{c}$ & 113.30 & $\mathrm{c}$ & 5.05 & $\mathrm{e}$ & 7.87 & $\mathrm{c}$ & 112.67 & $\mathrm{c}$ \\
\hline & 21 & 4.87 & $\mathrm{~h}$ & 7.77 & $\mathrm{~d}$ & 110.50 & de & 4.65 & $\mathrm{~g}$ & 7.63 & $\mathrm{~d}$ & 109.43 & $\mathrm{e}$ \\
\hline & 28 & 4.14 & $\mathrm{k}$ & 7.50 & $\mathrm{f}$ & 105.43 & $\mathrm{~h}$ & 3.94 & $\mathrm{j}$ & 7.27 & $\mathrm{gh}$ & 104.40 & $\mathrm{~h}$ \\
\hline & 35 & 3.43 & $\mathrm{O}$ & 7.10 & $\mathrm{~g}$ & 99.33 & $\mathrm{k}$ & 3.02 & $\mathrm{n}$ & 6.83 & $\mathrm{i}$ & 98.53 & $\mathrm{k}$ \\
\hline \multirow{6}{*}{$\mathrm{CaCl} 25 \%$} & $\mathbf{0}$ & 6.01 & $\mathrm{a}$ & 8.50 & $\mathrm{a}$ & 120.80 & $\bar{a}$ & 5.93 & $\mathrm{a}$ & 8.30 & $\bar{a}$ & 119.50 & $\mathrm{a}$ \\
\hline & 7 & 5.64 & $\mathrm{c}$ & 8.03 & $\mathrm{c}$ & 113.53 & $\mathrm{c}$ & 5.45 & $\mathrm{c}$ & 7.87 & $\mathrm{c}$ & 112.37 & $\mathrm{c}$ \\
\hline & 14 & 5.21 & $\mathrm{f}$ & 7.77 & $\mathrm{~d}$ & 111.33 & $\mathrm{~d}$ & 4.87 & $\mathrm{f}$ & 7.67 & $\mathrm{~d}$ & 110.27 & $\mathrm{~d}$ \\
\hline & 21 & 4.75 & $\mathrm{i}$ & 7.53 & ef & 108.13 & $\mathrm{~g}$ & 4.51 & $\mathrm{~h}$ & 7.33 & $\mathrm{fg}$ & 107.20 & $\mathrm{~g}$ \\
\hline & 28 & 3.95 & $\mathrm{~m}$ & 7.20 & $\mathrm{~g}$ & 102.37 & $\mathrm{i}$ & 3.68 & $\mathrm{k}$ & 6.87 & $\mathrm{i}$ & 101.40 & $\mathrm{i}$ \\
\hline & 35 & 3.16 & $\mathrm{q}$ & 6.73 & $\mathrm{~h}$ & 94.33 & $\mathrm{~m}$ & 2.77 & $\mathrm{o}$ & 6.47 & $\mathrm{j}$ & 93.23 & $\mathrm{~m}$ \\
\hline \multirow{6}{*}{ Hot water } & $\mathbf{0}$ & 6.01 & $\mathrm{a}$ & 8.50 & $\mathrm{a}$ & 120.80 & $\mathrm{a}$ & 5.93 & $\mathrm{a}$ & 8.30 & $\mathrm{a}$ & 119.50 & $\mathrm{a}$ \\
\hline & 7 & 5.42 & $\mathrm{~d}$ & 7.83 & $\mathrm{~cd}$ & 111.20 & d & 5.24 & $\mathrm{~d}$ & 7.70 & d & 110.30 & $\mathrm{~d}$ \\
\hline & 14 & 4.96 & $\mathrm{~g}$ & 7.43 & $\mathrm{f}$ & 109.33 & $\mathrm{f}$ & 4.63 & $\mathrm{~g}$ & 7.47 & ef & 108.50 & $\mathrm{f}$ \\
\hline & 21 & 4.23 & $\mathrm{j}$ & 7.17 & $\mathrm{~g}$ & 105.37 & $\mathrm{~h}$ & 4.05 & $\mathrm{i}$ & 7.13 & $\mathrm{~h}$ & 104.47 & $\mathrm{~h}$ \\
\hline & 28 & 3.62 & $\mathrm{n}$ & 6.83 & $\mathrm{~h}$ & 98.37 & 1 & 3.34 & 1 & 6.53 & $\mathrm{j}$ & 97.30 & 1 \\
\hline & 35 & 2.64 & $\mathrm{r}$ & 6.33 & $\mathrm{i}$ & 91.50 & $\mathrm{n}$ & 2.22 & $\mathrm{p}$ & 6.03 & $\mathrm{k}$ & 90.47 & $\mathrm{n}$ \\
\hline \multirow{6}{*}{ Control } & $\overline{\mathbf{0}}$ & 6.01 & $\mathrm{a}$ & 8.50 & $\mathrm{a}$ & 120.80 & $\mathrm{a}$ & 5.93 & $\mathrm{a}$ & 8.30 & $\bar{a}$ & 119.50 & $a$ \\
\hline & 7 & 4.96 & $\mathrm{~g}$ & 7.73 & de & 109.67 & ef & 4.85 & $\mathrm{f}$ & 7.57 & de & 108.23 & $\mathrm{f}$ \\
\hline & 14 & 4.03 & 1 & 7.17 & $\mathrm{~g}$ & 105.40 & $\mathrm{~h}$ & 4.05 & $\mathrm{i}$ & 7.23 & $\mathrm{gh}$ & 104.33 & $\mathrm{~h}$ \\
\hline & 21 & 3.34 & $\mathrm{p}$ & 6.87 & $\mathrm{~h}$ & 101.40 & $\mathrm{j}$ & 3.13 & $\mathrm{~m}$ & 6.77 & $\mathrm{i}$ & 100.43 & $\mathrm{j}$ \\
\hline & 28 & 2.43 & $\mathrm{~s}$ & 6.47 & $\mathrm{i}$ & 94.47 & $\mathrm{~m}$ & 2.24 & $\mathrm{p}$ & 6.07 & $\mathrm{k}$ & 93.57 & $\mathrm{~m}$ \\
\hline & 35 & 1.02 & $\mathrm{t}$ & 6.03 & $\mathrm{j}$ & 87.33 & o & 1.05 & $\mathrm{q}$ & 5.60 & 1 & 86.43 & o \\
\hline \multicolumn{2}{|c|}{ МCP $1.5 \%$} & 4.92 & $\mathrm{~A}$ & 7.86 & $\mathrm{~A}$ & 110.96 & $\mathrm{~A}$ & 4.69 & $\mathrm{~A}$ & 7.66 & $\mathrm{~A}$ & 109.99 & $\mathrm{~A}$ \\
\hline \multicolumn{2}{|c|}{$\mathrm{CaCl} 25 \%$} & 4.79 & B & 7.63 & B & 108.42 & B & 4.53 & B & 7.42 & B & 107.33 & B \\
\hline \multirow{2}{*}{\multicolumn{2}{|c|}{$\begin{array}{c}\text { Hot water } \\
\text { Control }\end{array}$}} & 4.48 & $\mathrm{C}$ & 7.35 & $\mathrm{C}$ & 106.09 & $\mathrm{C}$ & 4.24 & $\mathrm{C}$ & 7.19 & $\mathrm{C}$ & 105.09 & $\mathrm{C}$ \\
\hline & & 3.63 & D & 7.13 & D & 103.18 & $\mathrm{D}$ & 3.54 & D & 6.92 & D & 102.08 & D \\
\hline & $\mathbf{0}$ & 6.01 & $\mathrm{~A}$ & 8.50 & $\mathrm{~A}$ & 120.80 & $\mathrm{~A}$ & 5.93 & $\mathrm{~A}$ & 8.30 & $\mathrm{~A}$ & 119.50 & $\mathrm{~A}$ \\
\hline & 7 & 5.44 & B & 7.97 & $\mathrm{~B}$ & 112.70 & B & 5.27 & B & 7.80 & B & 111.58 & $\mathrm{~B}$ \\
\hline & 14 & 4.89 & $\mathrm{C}$ & 7.60 & $\mathrm{C}$ & 109.84 & $\mathrm{C}$ & 4.65 & $\mathrm{C}$ & 7.56 & $\mathrm{C}$ & 108.94 & $\mathrm{C}$ \\
\hline & 21 & 4.30 & $\mathrm{D}$ & 7.33 & $\mathrm{D}$ & 106.35 & $\mathrm{D}$ & 4.09 & $\mathrm{D}$ & 7.22 & $\mathrm{D}$ & 105.38 & $\mathrm{D}$ \\
\hline & 28 & 3.54 & $\mathrm{E}$ & 7.00 & $\mathrm{E}$ & 100.16 & $\mathrm{E}$ & 3.30 & $\mathrm{E}$ & 6.68 & $\mathrm{E}$ & 99.17 & $\mathrm{E}$ \\
\hline & 35 & 2.56 & $\mathrm{~F}$ & 6.55 & $\mathrm{~F}$ & 93.13 & $\mathrm{~F}$ & 2.27 & $\mathrm{~F}$ & 6.23 & $\mathrm{~F}$ & 92.17 & $\mathrm{~F}$ \\
\hline
\end{tabular}

Values followed by the same letter $(s)$ are not significantly different at $5 \%$.

\subsection{Polyphenol oxidase activity}

Data in Table (3) show the inhibitory effect of some postharvest treatments and their impact on polyphenol oxidase activity of sweet pepper fruits during storage. It could be concluded that increase in the activity of polyphenol oxidase with the prolongation of storage till the end of storage period in both seasons, these results are similar with Shehata et al., 2009.

From the other side, the effect of postharvest treatments, data showed that sweet pepper fruits treated with 1-Methylcyclopropene (1.5\%) inhibit the activity of polyphenol oxidase, followed by calcium chloride $\mathrm{CaCl}_{2}(1.5 \%)$. The lowest percentage resulted in untreated control. These results were achieved in the two seasons; the decrease in $\mathrm{pH}$ and the reduction in PPO activity could be related to 1Methylcyclopropene (Huang et al., 2003, Tian et al., 2004, and Ilic et al., 2012). 
Table 3. Effect of some postharvest treatments on polyphenol oxidase activity (IU/mg protein), a* and $\mathrm{L}^{*}$ value of sweet pepper fruits during storage at $10^{\circ} \mathrm{C}$ in 2015 and 2016 seasons.

\begin{tabular}{|c|c|c|c|c|c|c|c|c|c|c|c|c|c|}
\hline \multirow[b]{2}{*}{ Treatments } & \multirow[b]{2}{*}{$\begin{array}{c}\text { Days } \\
\text { after } \\
\text { storage }\end{array}$} & \multicolumn{6}{|c|}{ First season (2015) } & \multicolumn{6}{|c|}{ Second season (2016) } \\
\hline & & \multicolumn{2}{|c|}{$\begin{array}{c}\text { Polyphenol } \\
\text { oxidase } \\
\text { activity } \\
\text { (IU/mg } \\
\text { protein) }\end{array}$} & \multicolumn{2}{|c|}{$\mathbf{L} *$ Value } & \multicolumn{2}{|c|}{ a*Value } & \multicolumn{2}{|c|}{$\begin{array}{c}\text { Polyphenol } \\
\text { oxidase } \\
\text { activity } \\
\text { (IU/mg } \\
\text { protein) } \\
\end{array}$} & \multicolumn{2}{|c|}{ L*Value } & \multicolumn{2}{|c|}{ a*Value } \\
\hline \multirow{6}{*}{ MCP $1.5 \%$} & $\mathbf{0}$ & 98.60 & $\mathrm{p}$ & 38.62 & $\mathrm{a}$ & 20.42 & $\mathrm{~s}$ & 98.80 & $\mathrm{r}$ & 37.51 & $\mathrm{a}$ & 21.83 & $\mathrm{u}$ \\
\hline & 7 & 102.47 & o & 35.26 & $\mathrm{~b}$ & 24.63 & $\mathrm{r}$ & 103.60 & $\mathrm{q}$ & 34.82 & $\mathrm{~b}$ & 24.06 & $\mathrm{t}$ \\
\hline & 14 & 105.20 & $\mathrm{~m}$ & 32.35 & $\mathrm{f}$ & 28.43 & o & 107.23 & $\mathrm{n}$ & 31.15 & $\mathrm{f}$ & 28.22 & $\mathrm{p}$ \\
\hline & 21 & 110.43 & $\mathrm{j}$ & 28.93 & $\mathrm{j}$ & 33.37 & $\mathrm{k}$ & 112.40 & $\mathrm{k}$ & 27.86 & $\mathrm{j}$ & 32.54 & 1 \\
\hline & 28 & 115.40 & $\mathrm{~g}$ & 23.16 & $\mathrm{n}$ & 38.34 & $\mathrm{~g}$ & 118.27 & $\mathrm{~h}$ & 22.05 & $\mathrm{n}$ & 38.14 & $\mathrm{~h}$ \\
\hline & 35 & 121.37 & $\mathrm{~d}$ & 18.46 & $\mathrm{r}$ & 43.14 & $\mathrm{~d}$ & 124.17 & $\mathrm{e}$ & 17.23 & $\mathrm{r}$ & 42.93 & $\mathrm{~d}$ \\
\hline \multirow{6}{*}{$\mathrm{CaCl} 25 \%$} & 0 & 98.60 & $\mathrm{p}$ & 38.62 & $\mathrm{a}$ & 20.42 & $\mathrm{~s}$ & 98.80 & $r$ & 37.51 & $\mathrm{a}$ & 21.83 & $\mathrm{u}$ \\
\hline & 7 & 103.60 & $\mathrm{n}$ & 34.91 & $\mathrm{c}$ & 25.32 & $q$ & 104.57 & $\mathrm{p}$ & 33.15 & $\mathrm{c}$ & 25.05 & $\mathrm{~s}$ \\
\hline & 14 & 106.57 & 1 & 31.83 & $\mathrm{~g}$ & 29.04 & $\mathrm{n}$ & 108.23 & $\mathrm{~m}$ & 30.53 & $\mathrm{~g}$ & 28.93 & o \\
\hline & 21 & 112.53 & $\mathrm{~h}$ & 28.25 & $\mathrm{k}$ & 34.06 & $\mathrm{j}$ & 115.43 & $\mathrm{i}$ & 27.16 & $\mathrm{k}$ & 33.04 & $\mathrm{k}$ \\
\hline & 28 & 117.67 & $\mathrm{f}$ & 22.70 & o & 39.23 & $\mathrm{f}$ & 120.50 & $\mathrm{~g}$ & 21.63 & o & 39.14 & $\mathrm{~g}$ \\
\hline & 35 & 124.67 & $\mathrm{c}$ & 17.63 & $\mathrm{~s}$ & 44.34 & $\mathrm{c}$ & 127.20 & $\mathrm{~d}$ & 16.73 & $\mathrm{~s}$ & 43.34 & $\mathrm{c}$ \\
\hline \multirow{6}{*}{ Hot water } & $\mathbf{0}$ & 98.60 & $\mathrm{p}$ & 38.62 & $\mathrm{a}$ & 20.42 & $\mathrm{~s}$ & 98.80 & $\mathrm{r}$ & 37.51 & $\mathrm{a}$ & 21.83 & $\overline{\mathrm{u}}$ \\
\hline & 7 & 105.07 & $\mathrm{~m}$ & 34.63 & $\mathrm{~d}$ & 25.55 & $q$ & 106.27 & o & 32.72 & $\mathrm{~d}$ & 25.53 & $\mathrm{r}$ \\
\hline & 14 & 108.60 & $\mathrm{k}$ & 31.45 & $\mathrm{~h}$ & 29.44 & $\mathrm{~m}$ & 110.33 & 1 & 29.93 & $\mathrm{~h}$ & 29.45 & $\mathrm{n}$ \\
\hline & 21 & 115.47 & g & 27.81 & 1 & 34.63 & $\mathrm{i}$ & 118.37 & $\mathrm{~h}$ & 26.72 & 1 & 33.64 & $\mathrm{j}$ \\
\hline & 28 & 121.60 & $\mathrm{~d}$ & 22.03 & $\mathrm{p}$ & 39.94 & $\mathrm{e}$ & 124.33 & $\mathrm{e}$ & 21.14 & $\mathrm{p}$ & 39.74 & $\mathrm{f}$ \\
\hline & 35 & 128.27 & $\mathrm{~b}$ & 17.05 & $\mathrm{t}$ & 44.83 & $\mathrm{~b}$ & 132.37 & $\mathrm{~b}$ & 16.03 & $\mathrm{t}$ & 43.84 & $\mathrm{~b}$ \\
\hline \multirow{6}{*}{ Control } & $\mathbf{0}$ & 98.60 & $\mathrm{p}$ & 38.62 & $\mathrm{a}$ & 20.42 & $\mathrm{~s}$ & 98.80 & $\mathrm{r}$ & 37.51 & $\mathrm{a}$ & 21.83 & $\mathrm{u}$ \\
\hline & 7 & 107.23 & 1 & 34.15 & e & 26.14 & $\mathrm{p}$ & 108.20 & $\mathrm{~m}$ & 32.06 & $\mathrm{e}$ & 26.14 & $q$ \\
\hline & 14 & 111.33 & $\mathrm{i}$ & 30.86 & $\mathrm{i}$ & 30.22 & 1 & 113.33 & $\mathrm{j}$ & 29.04 & $\mathrm{i}$ & 31.32 & $\mathrm{~m}$ \\
\hline & 21 & 120.57 & $\mathrm{e}$ & 27.05 & $\mathrm{~m}$ & 36.15 & $\mathrm{~h}$ & 123.23 & $\mathrm{f}$ & 25.92 & $\mathrm{~m}$ & 35.92 & $\mathrm{i}$ \\
\hline & 28 & 125.33 & $\mathrm{c}$ & 21.06 & $\mathrm{q}$ & 42.95 & $\mathrm{~d}$ & 128.27 & $\mathrm{c}$ & 20.33 & $\mathrm{q}$ & 42.84 & $\mathrm{e}$ \\
\hline & 35 & 134.50 & $\mathrm{a}$ & 15.82 & $\mathrm{u}$ & 48.31 & $\mathrm{a}$ & 139.73 & $\mathrm{a}$ & 14.83 & $\mathrm{u}$ & 47.95 & $\mathrm{a}$ \\
\hline \multicolumn{2}{|c|}{ MCP $1.5 \%$} & 108.91 & $\mathrm{D}$ & 29.46 & $\mathrm{~A}$ & 31.39 & $\mathrm{D}$ & 110.74 & $\mathrm{D}$ & 28.44 & $\mathrm{~A}$ & 31.29 & $\mathrm{D}$ \\
\hline \multicolumn{2}{|c|}{$\mathrm{CaCl} 25 \%$} & 110.61 & $\mathrm{C}$ & 28.99 & B & 32.07 & $\mathrm{C}$ & 112.46 & $\mathrm{C}$ & 27.78 & B & 31.89 & $\mathrm{C}$ \\
\hline \multicolumn{2}{|c|}{ Hot water } & 112.93 & B & 28.60 & $\mathrm{C}$ & 32.47 & B & 115.08 & B & 27.34 & $\mathrm{C}$ & 32.34 & B \\
\hline \multicolumn{2}{|c|}{ Control } & 116.26 & A & 27.93 & D & 34.03 & A & 118.59 & $\mathrm{~A}$ & 26.62 & $\mathrm{D}$ & 34.33 & A \\
\hline & $\mathbf{0}$ & 98.60 & $\mathrm{~F}$ & 38.62 & A & 20.42 & $\mathrm{~F}$ & 98.80 & $\mathrm{~F}$ & 37.51 & A & 21.83 & $\mathrm{~F}$ \\
\hline & 7 & 104.59 & $\mathrm{E}$ & 34.74 & B & 25.41 & $\mathrm{E}$ & 105.66 & $\mathrm{E}$ & 33.19 & B & 25.19 & $\mathrm{E}$ \\
\hline & 14 & 107.92 & $\mathrm{D}$ & 31.62 & $\mathrm{C}$ & 29.28 & $\mathrm{D}$ & 109.78 & $\mathrm{D}$ & 30.16 & $\mathrm{C}$ & 29.48 & $\mathrm{D}$ \\
\hline & 21 & 114.75 & $\mathrm{C}$ & 28.01 & $\mathrm{D}$ & 34.55 & $\mathrm{C}$ & 117.36 & $\mathrm{C}$ & 26.91 & $\mathrm{D}$ & 33.78 & $\mathrm{C}$ \\
\hline & 28 & 120.00 & B & 22.24 & $\mathrm{E}$ & 40.12 & B & 122.84 & B & 21.29 & $\mathrm{E}$ & 39.96 & B \\
\hline & 35 & 127.20 & A & 17.24 & $\mathrm{~F}$ & 45.16 & A & 130.87 & $\mathrm{~A}$ & 16.21 & $\mathrm{~F}$ & 44.51 & A \\
\hline
\end{tabular}

Values followed by the same letter (s) are not significantly different at $5 \%$.

3.8. Color ( $L^{*}$ and $a^{*}$ value):-

Data in Table (3) indicate the effect of some postharvest treatments on color of sweet pepper fruits during storage. Data indicated that the colors of sweet pepper fruits decreased for $\mathrm{L}^{*}$ value and increase for $\mathrm{a}^{*}$ value with the prolongation of storage till the end of storage period in both seasons.

The colors of sweet pepper fruits were significant differences between the different treatments during storage period in both seasons. Fruits treated with 1- methylcyclopropene $1.5 \%$ were the lightest color (high $\mathrm{L}^{*}$ value), followed by calcium chloride $\mathrm{CaCl}_{2}$ $(1.5 \%)$ compared with untreated control darkest color (low $\mathrm{L}^{*}$ value).

In general, value for $\mathrm{a}^{*}$ increased during storage for all treatment in both seasons. Concerning the treatments data indicated that fruits treated with 1methylcyclopropene $1.5 \%$ were the lowest $\mathrm{a}^{*}$ value (low $a^{*}$ value) followed by Fruits treated with calcium chloride $\mathrm{CaCl}_{2} \quad(1.5 \%)$ compared to 
untreated fruits higher $a^{*}$ value (high $a^{*}$ value). Indeed, with this treatment the color of sweet pepper fruits was maintained, these results agreement with Ilic et al., 2009 and Ilic et al., 2012.

The interaction among treatments and storage period, showed that fruits dipped in 1methylcyclopropene gave lightest color (high $\mathrm{L}^{*}$ value) and lowest $\mathrm{a}^{*}$ value after 35 days of storage compared to all other tested treatments in both seasons.

\section{References}

A. O. A. C., 2012. Official methods of analysis of AOAC International. $19^{\text {th }}$ edition. Gaithersburg, MD, USA, Association of Analytical Communities.

Dogan, M.; Aslan, O. and Dogan, O. 2002. Substrate specificity, heat inactivation and inhabitation of polyphenol oxidase from different aubergine cultivars. Int. J. Food Sci. Technol. 37:415-423.

Fernández-Trujillo, J. P.; Serrano, J. M. and Martinez, J. A. 2009. Quality of red sweet pepper fruit treated with 1-MCP during a simulated post-harvest handling chain. Food Sci. 15:23-30.

Glowacz, M, L. M.; Mogren, Reade, J. P. H.; Cobb, A. H. and Monaghan, J. M. 2013. Can hot water treatments enhance or maintain postharvest quality of spinach leaves? Postharvest Biol. and Technol. 81:23-28.

Gonzalez-Aguilar, G. A.; Ayala-Zavala, J. F.; RuizCruz, S.; Acedo-Felix, E. and DiazCinco, M. E. 2004. Effect of temperature and modified atmosphere packaging on overall quality of fresh-cut bell peppers. LWT Food Sci. Technol. 37: 817-826.

Huang, X. M.; Zhang, Z. Q. and Duan, X. W. 2003. Effects of 1-Methylcyclopropene on storage quality of hot pepper (Capsicum frutescens) at room temperature. China Vegetables. 1:9-11.

Huber, D. J. 2008. Suppression of ethylene responses through application of 1Methylcyclopropene: A powerful tool for elucidating ripening and senescence mechanisms in climacteric and non climacteric fruits and vegetable. HortScience. 43:106-111.

Huber, D. J.; Hurr, B. M.; Lee, J. S. and Lee, J. H. 2010. 1-Methylcyclopropene sorption by tissues and cell-free extracts from fruits and vegetable: evidence for enzymatic 1-MCP metabolism. Postharvest Biol. and Technol. 56:123-130.

Ibrahim,H.A. and Abdullah, M. A. A., 2018 . Effects of 1-Methylcyclopropane on Quality of Tomato and Sweet Pepper Fruits during
Mixed Loads. Bioscience Research. 15(1):270-279.

Ilic, Z. S.; Radmila, T. and Yaacov, P. 2012. Influence of 1-Methylcyclopropene (1-MCP) on Postharvest Storage Quality in Green Bell Pepper Fruit. Food Bioprocess Technol. 5:2758-2767.

Ilic, Z.; Sunic, L.; Mirecki, N. and Fallik, E. 2014. Cultivars Differences in Keeping Quality and Bioactive Constituents of Bell Pepper Fruit during prolonged Storage. Journal of advances in Biotechnology. 4(1):313-318.

Ilic, Z.; Vinokur, Y.; Ben-Yosef, A.; Pertzelan, Y.; Alkalai-Tuvia, S. and Fallik, E. 2009. The influence of 1-MCP on chlorophyll, antioxidants activity and quality changes in "ever-green" and red pepper fruits after harvest. ActaHorticulturae. 830:643-650.

Lee, S. K. and Kader, A. A. 2000. Preharvest and postharvest factors influencing vitamin $\mathrm{C}$ content of horticultural crops. Postharvest. Biol. Technol. 20: 207-220.

Lurie, S. 1998. Postharvest heat treatments. Postharvest Biol. and Technol. 14: 257-269.

Madhavi, D. L. and Salunke, D. L. 1998. Tomato. In Handbook of vegetable science and technology: production, storage and processing (Salunkhe D. K. and Kadam S. S., ed). Marcel Dekker, NewYork, pp. 171-201.

Nirupama, P.; Neeta, B. G. and RamanaRao, T. V. 2010. Effect of Postharvest Treatments on Physicochemical Characteristics and Storage life of Tomato (Lycopersicon esculentum Mill.) Fruits during Storage. AmericanEurasian J. Agricultural \& Environmental Science. 9 (5): 470-479.

Ochie, C. O.; Barionny, F .M. and Woods, F. M. 1993. Calcium mediated postharvest changes in storability and fruit quality of peaches. Proceedings of the Florida State Horticultural Society. 106: 266-269.

Raffo, A.; Baiamonte, I. and Paoletti, F. 2008. Changes in antioxidants and taste-related compounds content during cold storage of fresh-cut red sweet peppers. Eur Food Resersh and Technology. 226: 1167-1174.

Sabir, F. K.; Kusvuran, S.; Dasgan, H. Y. and Agar, I. T. 2012. Effects of 1Methylcyclopropene treatment on postharvest life and quality in four tomatoes cultivars. The Journal of Animal \& Plant Sciences. 22(4):1086-1091.

Schirra, M.; D'Hallewin, G.; Ben-Yehoshua, S. and Fallik, E. 2000. Hostpathogen interactions modulated by heat treatment. Postharvest Biol. Technol. 21(1):71-85.

Senevirathna, P. A. W. A. N. K. and Daundasekera, W. A. M. 2010. Effect of postharvest calcium chloride vacuum infiltration on shelf life and quality of tomato 
(cv. Thilina)', Cey. J. Sci. (Bio. Sci). 39(1):35-44.

Shehata, S. A.; Hashem, M. Y.; Emam, M. S. and Rageh, M. A. 2009. Effect of hot water and calcium chloride treatments on fresh cut sweet pepper during cold storage. Annals of Agric. Sci., Moshtohor, 47(3):445-455.

Shehata, S.A.; Ibrahim, M.I.A. ; El-Mogy, M.M. and El-Gawad, K.F.A. 2013. Effect of hot water dips and modified atmosphere packaging on extending the shelf life of bell pepper fruits. Wulfenia Journal 20(3): 315328.

Sivakumar, D. and Fallik, E. 2013. Influence of heat treatments on quality retention of fresh and fresh-cut produce. Food Reviews International. 29:294-320.

Smith, D. L.; Stommel, J. R.; Fung, W. M.; Wang, C. Y. and Whitaker, B. D. 2006. Influence of cultivar and harvest method on postharvest storage quality of pepper (Capsicum annuum L.) fruit. Postharvest Biology and Technology. 42:243-247.
Snedecor, C. W. and Cochran, W. G. 1982 Statistical Methods. $7^{\text {th }}$ Ed. The lowa state Univ. Press. Ames. lowa, USA. PP: 325-330.

Thakur, K. S.; Jyoti, K., Kumar, S. and Gautum, S. 2017. Improvement of postharvest keeping quality of bell pepper (Capsicum annum L.) fruits treated with different chemicals following cold storage. Int. J. Curr. Microbiol. Appl. Sci. 6, 7:2462-2475.

Tian, M.; Gupta, D.; Lei, X. Y.; Prakash, S.; Xu, C. and Fung, R. W. M. 2004. Effects of low temperature and ethylene on alternative oxidase in green pepper (Capsicum annuиm L.) Journal of Horticultural Science \& Biotechnology. 79:493-499.

Watkins, C. B. 2006. The use of 1Methylcyclopropene (1-MCP) on fruits and vegetables. Biotechnology Advances. 24:389409.

Watkins, C. B. 2008. Overview of 1Methylcyclopropene trials and uses for edible horticultural crops. HortScience. 4:86-94.

\section{تحسين الجودة والقدرة التخزينية لثمار القلقل الحلو من خلال بعض معاملات ما بعد الحصاد.}

أجريت هذه التجربة لدراسة تأثير بعض معاملات ما بعد الحصاد على القدرة التخزينية وجودة ثمار الفلفل أثناء التخزين حيث تم زراعة نباتات الفلفل تحت صوب بلاسنيكية خلال موسمي 2015- 2016 و 201675\% تلوين وتم نقلها إلى ثلاجات قسم بحوث تداول الخضر - معهد بحوث البساتين - مركز البحوث الزراعية لاجراء معاملات على الثمار

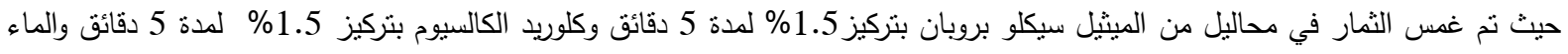

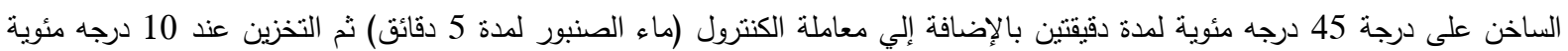
90- 95٪ رطوبة نسبية وتنجيل القراءات لتقدير التغيرات في صفات جوده ثمار الفلفل أثناء التخزين كل 7 أيام لمدة 35 يومًا. اوضحت النتائج أن دلالات جودة الثمار التي تتمل المظهر العام، الصلابة، المواد الصلبة الذائبة الكلية ومحتوى حامض الاسكوربيك قد انخفضت أنثاء التخزين بالاضافة الي زيادة الفقد في الوزن، التالف فى الثمار و نشاط انزيم البولى فينول اوكسيديز مع إطالة فترة التخزين.

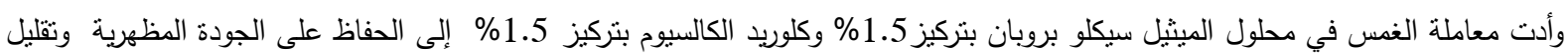

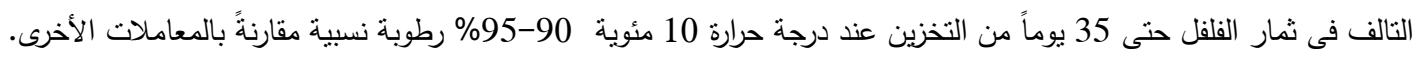
كما أدت معاملة الغمس في محلول الميثيل سيكلو بروبان بتركيز 1.5\% إلى الحفاظ على خصائص الجودة (الصلابة، المواد الصلبة الذائبة الكلية،محتوى حامض الاسكوربيك، نشاط انزيم البولى فينول اوكسيديز و التغير فى اللون) حتى 35 يوماً من التخزين عند درجة حرئ حرارة 10 مئوية 90-95 رطوبة نسبية مقارنةً بالمعاملات الأخرى. 